\title{
Genetics of Diabetes in Nauru: Effects of Foreign Admixture, HLA Antigens and the Insulin-Gene-Linked Polymorphism
}

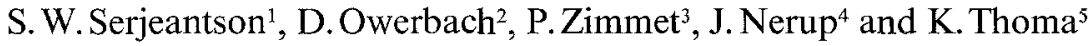 \\ ${ }^{1}$ Department of Human Biology, John Curtin School of Medical Research, Australian National University, Canberra, Australia, \\ ${ }^{2}$ Hagedorn Research Laboratory, Gentofte, Denmark, ${ }^{3}$ WHO Collaborating Centre for the Epidemiology of Diabetes Meilitus, \\ Southern Memorial Hospital, Caulfield, South Victoria, Australia, ${ }^{4}$ Steno Memorial Hospital, Gentofte, Denmark and \\ ${ }^{5}$ Nauru General Hospital, Republic of Nauru, Central Pacific
}

\begin{abstract}
Summary. Genetic factors play a major role in predisposition to diabetes in the Micronesian population of Nauru. In people aged 60 years and older, $83 \%$ of full-blooded Nauruans were diabetic compared with $17 \%$ of those with ancestral foreign admixture, as detected by HLA typing. HLA distributions also showed a small increased risk for early onset of diabetes ( $<46$ years) associated with HLA-Bw22 (Bw56). Variation in the restriction fragment length of DNA near the insulin
\end{abstract}

gene was found, but was not associated with diabetes. The distribution in fragment lengths, previously reported in Caucasoids, was observed in healthy Polynesians, Melanesians and Micronesians.

Key words: Type 2 diabetes, HLA-Bw22, insulin gene, Nauru, Central Pacific, diabetes genetics.
The genetic component in Type 2 (non-insulin-dependent) diabetes mellitus, in Caucasoids at least, is substantially greater than in Type 1 (insulin-dependent) diabetes [1]. In Type 1 diabetes, specific HLA-antigen associations have been identified in Caucasoids [2, 3], Japanese [3] and Chinese [4], but the major gene or genes predisposing to Type 2 diabetes remain(s) elusive. This is despite reports of minor associations of Type 2 diabetes with HLA-A2 in both the Xhosa in Southern Africa [5] and the Pima of south-western United States [6] and with HLA-Bw61 in Indians from Uttar Pradesh resident in Fiji [7] and South Africa [8]. In Caucasoids, Type 2 diabetes is not associated with HLA antigens but possibly with DNA insertion sequences adjacent to the $5^{\prime}$ end of the insulin gene $[9,10,11]$. This observation remains controversial since it has not been confirmed by some workers $[12,13]$.

We have investigated both HLA and insulin-gene region DNA insertion (deletion) polymorphisms in diabetes in the population of Nauru, a Micronesian group with an adult prevalence of Type 2 diabetes greater than $20 \%$ [14]. We have also looked at possible moderating effects of foreign genetic admixture on diabetes in people claiming to be pure Nauruan, but with ancestral foreign admixture as detected by HLA-typing. In addition, we provide, for the first time, population gene frequencies of restriction fragment lengths of the insulin gene in Polynesians, Melanesians and Micronesians.

\section{Subjects and Methods}

\section{Ethnographic Background}

Nauru is an isolated island in the Central Pacific. Ethnographically, the people are Micronesian with prehistoric genetic affinities with Mongoloid and Melanesian groups [15]. The small population of 4,000 Nauruans, including 2,000 adults, has a limited gene pool since it has contracted markedly even within recorded history. The population was 1476 in 1900 [16] but suffered severe losses due to introduction of infectious diseases, high infant mortality in droughts of 1924-1926 and adult mortality in the Second World War [17].

Thus, the Nauru population has been limited by founder effects, has passed through several genetic bottlenecks and has been discouraged, certainly in recent years, from miscegenation by laws that discourage marriage with non-Nauruans. However, the gene pool is not entirely free of foreign genetic admixture and some of the surnames and HLA haplotypes of early castaways [18] are evident in the modern population of Naunt.

\section{Study Populations}

The Nauruans were studied with informed consent during a 3-week period in January, 1982, when adults aged 20 years and older presented at medical survey that included an oral glucose tolerance test following a $75 \mathrm{~g}$ glucose load. The procedures were as described previously for the 1975 medical survey of Nauru [19], except that complete ascertainment of adults was sought and the subgroup selected for genetic studies was drawn from each of the 14 electoral districts.

The prevalence of diabetes is so high in Nauru that suitable controls, who do not have the presumed diabetogenic phenotype, are difficult to identify and any genetic differences in diabetes suceptibility may be manifested in terms of differential ages of onset. Thus, for 
Table 1. HLA-A and HLA-B antigen distributions in Type 2 diabetic and non-diabetic subjects from Nauru

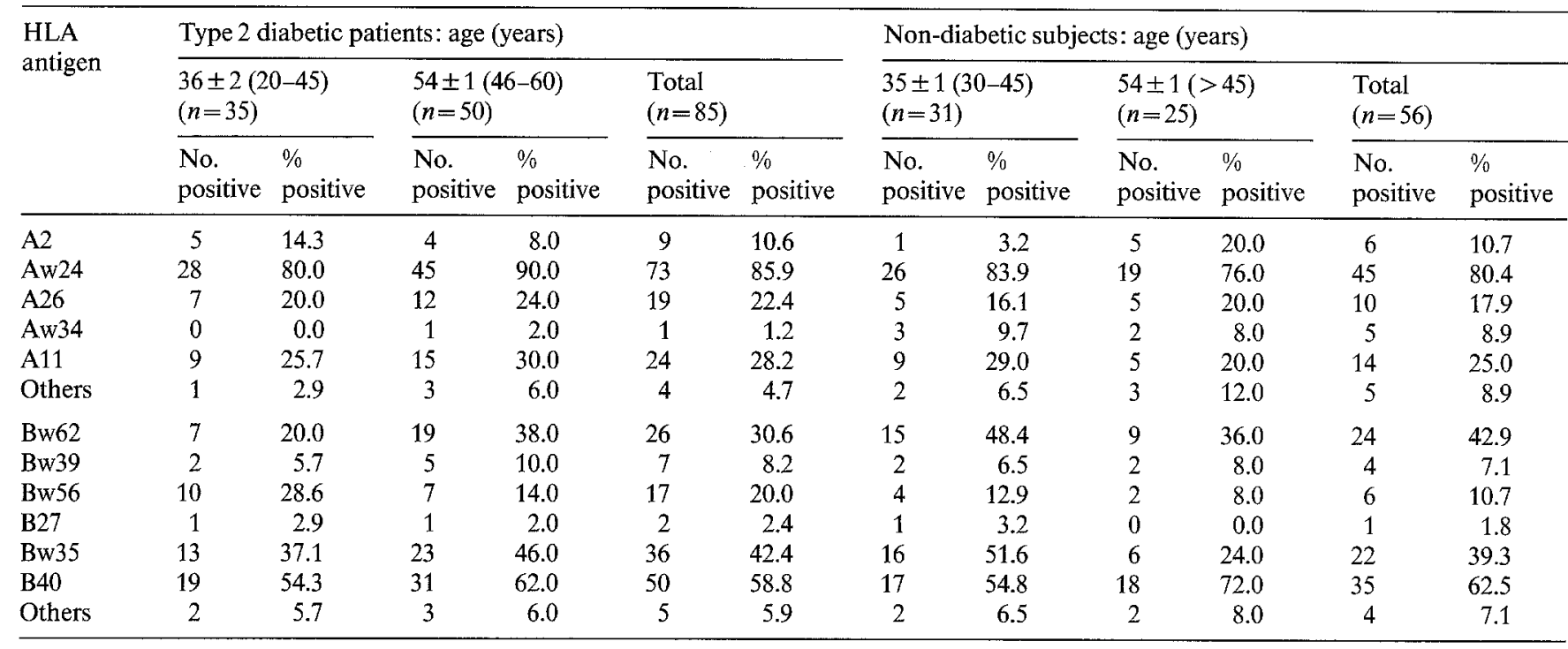

Age expressed as mean \pm SEM (range)

comparison of HLA antigen and insulin-gene insertion polymorphisms in diabetic and non-diabetic subjects, data have been tabulated for the 30-45 year and 46-60 year cohorts with diabetic patients older than 60 years and non-diabetic subjects younger than 30 years excluded from the comparisons. Further, the control series has been confined to non-diabetic subjects with 2-h post-load plasma glucose concentrations $<8.0 \mathrm{mmol} / \mathrm{l}$. Patients were diagnosed or confirmed as diabetic according to criteria suggested by the WHO Expert Committee on Diabetes Mellitus [20], i. e. fasting plasma glucose $\geqslant 8.0$ $\mathrm{mmol} / 1$ or with $2-\mathrm{h}$ plasma glucose levels equal to or $>11.0 \mathrm{mmol} / \mathrm{l}$. Thirtytwo percent of the sample HLA-typed had diabetic retinopathy. Diabetic patients with and without retinopathy did not differ in HLA distributions or in restriction length phenotypes and have been combined for comparison with non-diabetic subjects.

For analysis of restriction-length fragment polymorphisms of the insulin gene in other Pacific populations, Polynesians from the Wallis Islands, located east of Fiji, and Melanesians from New Caledonia were studied. These subjects were not diabetic according to oral glucose tolerance tests.

\section{Laboratory analysis}

HLA-typing was performed in Nauru at $22^{\circ} \mathrm{C}$ and according to standard microcytotoxic techniques described elsewhere [21], using 176 antisera to define HLA-A, -B and -C antigens on freshly-drawn lymphocytes. In addition, lymphocytes were frozen within $5 \mathrm{~h}$ of collection in liquid nitrogen for subsequent DNA extraction.

DNA was isolated from lymphocytes according to standard procedures [22] and digested with the restriction enzyme $\mathrm{Bgl}$ I. DNA fragments were then separated by size on a 1\% agarose gel, transferred to commercial filters (Gene Screen, New England Nuclear, Boston, USA) and hybridized with a ${ }^{32}$ P-labelled insulin DNA probe [10]. Filters, after washing, were exposed to X-Omat RP film at $-70^{\circ} \mathrm{C}$ for 8 days. Small Bgl I restriction fragments $(3.3 \mathrm{~Kb})$ have been designated $\mathrm{L}$ (lower electrophoretic type) and large fragments $(>4.3 \mathrm{~Kb}$ ) designated $\mathrm{U}$ (upper electrophoretic type) following the nomenclature of Owerbach and Nerup [10].

\section{Results}

HLA-A and HLA-B antigen frequencies for diabetic and non-diabetic subjects in two age groups are given in
Table 1. The antigen profile is comparatively restricted in full-blooded Nauruans, with only 6 HLA-A and 6 HLA-B locus specificities. Antigens tabulated as 'other' include sporadic instances of A1, A3, A25, A29, Aw31, B7, Bw44, B18 and Bw50. These antigens are unknown in other Pacific populations [23], with the exception of rare instances of $\mathrm{B} 18$, and can be assumed foreign to Nauru since they often occurred in known Caucasoid linkage groups such as A25, B18; A29, Bw44 and A3, B7.

The most appropriate comparison for examining HLA-associated age-of-onset effects is between young diabetic patients ( $<46$ years) and older non-diabetic subjects ( $\geqslant 46$ years). Comparison of these two groups shows no differences in HLA-A locus antigen distributions, but at the HLA-B locus there is an increase in frequency of $\mathrm{Bw} 22$ (Bw56) in diabetic patients $\left(\chi^{2}=3.86\right.$, $p=0.05$ ). This difference is not significant when comparisons are made within age groups nor when age groups are combined. The increase in Bw22 in young diabetic patients is accompanied by a decreased frequency of Bw62 which is statistically significant when compared with young non-diabetic subjects $\left(\chi^{2}=5.96\right.$, $0.01<\mathrm{p}<0.05)$ and with the total control series $\left(\chi^{2}=5.01,0.01<p<0.05\right)$.

Table 2 gives the distributions of individuals with foreign HLA types according to glucose tolerance test results. Individuals with foreign antigens at both the HLA-A and HLA-B loci are included only once in Table 2. The highest proportion of detectable admixture occurred in those with impaired glucose tolerance (2-h post-load plasma glucose: $8.0-10.9 \mathrm{mmol} / 1)$, significantly higher than in diabetic patients $\left(\chi_{1}^{2}=7.80, p<\right.$ 0.01 ) but not different from those with normal glucose tolerance. The divergent risks for diabetes in those with and without foreign admixture are most marked in 
Table 2. The distributions of individuals with foreign HLA types according to diabetic, impaired and normal glucose tolerance test results

\begin{tabular}{|c|c|c|c|c|c|c|c|c|}
\hline Age (years) & \multicolumn{2}{|c|}{ Diabetic patients } & \multicolumn{2}{|c|}{ Impaired glucose tolerance } & \multicolumn{2}{|c|}{ Normal glucose tolerance } & \multicolumn{2}{|c|}{ Relative risk ${ }^{\mathrm{a}}$} \\
\hline $46-59$ & 46 & 8.7 & 9 & 22.2 & 22 & 9.1 & 1.22 & NS \\
\hline $60+$ & 20 & 5.0 & 6 & 66.7 & 3 & 33.3 & 4.96 & 0.003 \\
\hline Total & 100 & 7.0 & 32 & 25.0 & 99 & 12.1 & 1.76 & 0.054 \\
\hline
\end{tabular}

${ }^{a}$ Risk for diabetes if pure Nauruan ancestry compared with risk if foreign admixture; NS = not significant

Table 3. Distribution of UU, UL and LL genotypes in Type 2 diabetic and non-diabetic subjects from Nauru

\begin{tabular}{|c|c|c|c|c|c|c|c|c|c|c|c|c|c|c|c|}
\hline \multirow[t]{2}{*}{ Age (years) } & \multicolumn{7}{|c|}{ Type 2 diabetic patients } & \multirow[t]{2}{*}{ Age (years) } & \multicolumn{7}{|c|}{ Non-diabetic subjects } \\
\hline & $\frac{\text { Total }}{\text { No. }}$ & No. & $\%$ & No. & $\%$ & No. & $\%$ & & $\frac{\text { Total }}{\text { No. }}$ & No. & $\%$ & No. & $\%$ & No. & $\%$ \\
\hline & & & & & & & & $20-29$ & 26 & 0 & 0.0 & 8 & 30.8 & 18 & 69.2 \\
\hline $20-45$ & 19 & 0 & 0.0 & 7 & 36.8 & 12 & 63.2 & $30-45$ & 19 & 1 & 5.3 & 8 & 42.1 & 10 & 52.6 \\
\hline $46-60$ & 30 & 2 & 6.7 & 12 & 40.0 & 16 & 53.3 & $>45$ & 15 & 0 & 0.0 & 5 & 33.3 & 10 & 66.7 \\
\hline All ages & 58 & 2 & 3.4 & 24 & 41.4 & 32 & 55.2 & All ages & 60 & 1 & 1.7 & 21 & 35.0 & 38 & 63.3 \\
\hline
\end{tabular}

Table 4. Distribution of $U$ and $L$ phenotypes and allele frequencies in normal subjects from four ethnic groups

\begin{tabular}{|c|c|c|c|c|c|c|c|c|}
\hline \multirow{2}{*}{$\begin{array}{l}\text { Ethnic } \\
\text { group }\end{array}$} & \multicolumn{2}{|l|}{ UU } & \multicolumn{2}{|l|}{ UL } & \multicolumn{2}{|l|}{ LL } & \multicolumn{2}{|l|}{ U allele } \\
\hline & No. & $\%$ & No. & $\%$ & No. & $\%$ & $\begin{array}{l}\text { Fre- } \\
\text { quency }\end{array}$ & $\begin{array}{l}\text { Vari- } \\
\text { ance }\end{array}$ \\
\hline $\begin{array}{l}\text { Micronesian } \\
(n=60)\end{array}$ & 1 & 1.7 & 21 & 35.0 & 38 & 63.3 & 0.192 & 0.0013 \\
\hline $\begin{array}{l}\text { Polynesian } \\
(n=46)\end{array}$ & 6 & 13.0 & 18 & 39.1 & 22 & 47.8 & 0.326 & 0.0024 \\
\hline $\begin{array}{l}\text { Melanesian } \\
(n=36)\end{array}$ & 2 & 5.6 & 4 & 11.1 & 30 & 83.3 & 0.111 & 0.0014 \\
\hline $\begin{array}{l}\text { Caucasoid } \\
{[24](n=52)}\end{array}$ & 2 & 3.8 & 24 & 46.2 & 26 & 50.0 & 0.269 & 0.0019 \\
\hline
\end{tabular}

those aged 60 years and older. In this age group, $95 \%$ of diabetic patients had full-blooded Nauruan ancestry on the basis of HLA typing, compared with $44 \%$ of nondiabetic subjects. The only diabetic patient aged over 60 years and with foreign admixture was a 75-year-old woman with 2-h plasma glucose concentration of $13.2 \mathrm{mmol} / 1$.

The distributions of UU, UL and LL genotypes in unrelated diabetic patients are given in Table 3 and are compared with non-diabetic subjects with normal glucose tolerance. There are no differences in genotype distributions in diabetic and non-diabetic subjects in any age group. The diabetic sample aged 60 years or younger includes three people with detectable foreign admixture and the control series ( $\geqslant 30$ years) five subjects with a foreign HLA haplotype.

Table 4 provides the frequencies of the $U$ allele in normal subjects in three Pacific populations for com-

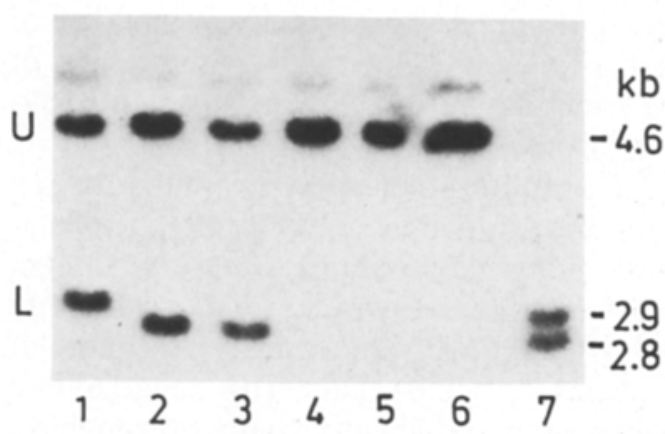

Fig. 1. Autoradiogram of insulin-gene-containing DNA sequences in DNA digested with Bgl I from a Polynesian family. (1) Wife, (2) husband, (3) child 1, (4) child 2, (5) child 3, (6) child 4, (7) child 5

parison with the published frequency [24] for normal Caucasoids. Only the Melanesian frequency is different from that in Caucasoids $\left(\chi_{1}^{2}=6.63, p=0.01\right)$.

The sizes of the $\mathrm{U}$ and $\mathrm{L}$ insertions in Pacific populations are also comparable with those observed in Caucasoids [10]. In Caucasoids, the $U$ allele ranges in size from 4.3-5.0 kilobases $(\mathrm{Kb})$ compared with $4.4-5.6 \mathrm{~Kb}$ in Melanesians. The $\mathrm{L}$ alleles can range in size in Caucasoids from $2.7-3.2 \mathrm{~Kb}$ and varied between $2.7-2.9 \mathrm{~Kb}$ in all Pacific groups, with the exception of two examples in Nauru of L insertions of $3.3 \mathrm{~Kb}$.

Figure 1 shows an autoradiogram, after hybridization with the ${ }^{32}$ P-labelled insulin probe, of $U$ and $L$ insertions in a Polynesian family. Both parents are heterozygous UL, but have different sizes of the L insertion as is apparent on the autoradiogram and confirmed in child number 5, who is heterozygous for two $\mathrm{L}$ subtypes. Child number 1 is heterozygous UL and children 
numbers 2, 3 and 4 are homozygous UU, clearly showing the Mendelian inheritance of $\mathrm{U}$ and $\mathrm{L}$ insertions in this Polynesian family.

\section{Discussion}

We have provided the first evidence for a genetic component in Type 2 diabetes in the Pacific by finding, in the population of Nauru, that ancestral foreign admixture has a protective effect against diabetes. This is most marked in the older generations, possibly reflecting a lesser diluting of imported genes and concomitantly, more accurate detection of foreign admixture by HLA typing. Also, in the older generations, a higher proportion of persons with the diabetogenic phenotype are likely to be detected by glucose tolerance tests.

In the generation aged 60 years and older, $83 \%$ of full-blooded Nauruans in the genetic sample had diabetes, compared with only $17 \%$ of part-Nauruans. That this difference is due to genetic influences seems indisputable, since there is no evidence today to suggest differential diets or life-styles of part and full-blooded Nauruans. In addition, body mass index, a measure of obesity defined as weight $(\mathrm{kg})$ divided by the square of height (metres) did not differ between part and fullblooded men or women.

The highest proportion of foreign admixture occurred in those with impaired glucose tolerance, suggesting a moderating codominant effect of foreign genes at one or more loci. However, the great majority of Nauruans have no European ancestry and most of these have diabetes by age 60 years. This suggests that the genes predisposing to diabetes, whether through selection or genetic drift, have attained extraordinarily high frequencies. Given the extreme geographical isolation of Nauru and severe constrictions in population size, the genetic profile of Nauruans may well reflect the impact of genetic drift. Indeed, there is, for instance, a high frequency (7\%) of $C 6^{\text {Nauru }}[25]$, an iso-electric variant of the complement component $\mathrm{C} 6$ that is rare or absent in other populations. Also, a variant of erythrocyte glyoxalase attains polymorphic frequencies in Nauru [26] although it is completely absent from ten other Asian and Pacific populations studied. The effects of selection, however, in contributing to uniquely high frequencies of a diabetogenic phenotype, cannot be discounted since the impact of drought and famine on infant mortality is well-documented for the island [17], with much of the mortality attributed to vitamin B1 deprivation [27].

The genes predisposing to diabetes are so ubiquitous in full-blooded Nauruans that our studies focussed on possible genetic differences in age of onset of the disease, by studying two genomic segments claimed to be associated with Type 2 diabetes in other ethnic groups.
In the major histocompatibility complex there was a small but significant increase in HLA-Bw22 in younger diabetic patients. The significance of this association has not been corrected for the number of antigens tested, due to a priori assumptions based on our previously observed significant increase in HLA-Bw22 in Polynesian diabetic patients [28]. This antigen may well be associated with a real but small increase in risk for Type 2 diabetes in the Pacific.

The second genetic system examined, variation in the $\mathrm{Bgl} \mathrm{I}$ restriction fragment lengths containing the insulin gene, showed no association with age-of-onset of diabetes in Nauru. There were, however, two distinct size classes of alleles: $\mathrm{Bgl} I$ restriction fragments of $2.7-3.3 \mathrm{~Kb}$ (L-alleles) and 4.4-5.0 Kb (U-alleles). No $\mathrm{Bgl}$ I sequences were found between 3.3 and $4.4 \mathrm{~Kb}$. Indeed, the bimodal distribution of restriction fragments has been maintained in an outbred Caucasoid population [24], Melanesians and Polynesians as well as in Micronesians. A regulatory role for $U$ alleles on glucose concentration has been suggested in the Caucasoid population [29]. In Micronesians, they may also play a regulatory role, though they are currently undetected because of the effects of other more dominant genes.

Our data suggest a genetic aetiology in the Type 2 diabetes of Nauru. The data support earlier claims of minor MHC influences in Type 2 diabetes in some ethnic groups [6,7], especially in age-of-onset effects and suggest, by the clear absence of a diabetes association, with the $\mathrm{U}$ and $\mathrm{L}$ restriction fragment types containing the insulin gene that the genes leading to diabetes in Nauru may differ from those claimed to lead to Type 2 diabetes in some Caucasoids $[10,11]$.

Acknowledgements. The authors thank Ms P. Ranford and L. Aagaard for excellent technical assistance. We are grateful for the help and encouragement provided by the Minister of Health, Republic of Nauru. This work was supported by NIH Grant 1RO1 AM 25446.

\section{References}

1. Barnett AH, Eff C, Leslie RDG, Pyke D (1981) Diabetes in identical twins. A study of 200 pairs. Diabetologia 20: 87-93

2. Nerup J, Platz P, Ánderson OO, Christy M, Lyngse J, Poulsen JE, Ryder LP, Svejgaard A (1974) HLA antigens and diabetes mellitus. Lancet 2: 864-866

3. Svejgaard A, Platz P, Ryder LP (1980) Insulin-dependent diabetes mellitus. In: Terasaki PI (ed) Histocompatibility testing 1980. UCLA Tissue Typing Laboratory, Los Angeles pp 638-656

4. Maeda H, Takeuchi F, Juji T, Akanuma Y, Kasuga M, Lee YS, Kosaka K, Tsai SH (1980) HLA-DRW3 in juvenile onset diabetes mellitus in Chinese. Tissue Antigens 15:173-176

5. Briggs BR, Jackson WPU, Du Toit ED, Botha MC (1980) The histocompatibility (HLA) antigen distribution in South African blacks (Xhosa). Diabetes 29:68-70

6. Williams RC, Knowler WC, Butler WJ, Pettitt DJ, Lisse JR, Bennett PH, Mann DL, Johnson AH, Terasaki PI (1981) HLA-A2 and Type 2 (insulin independent) diabetes mellitus in Pima Indians: an association of allele frequency with age. Diabetologia 21: $460-463$

7. Serjeantson SW, Ryan DP, Ram P, Zimmet P (1980) HLA and 
non-insulin-dependent diabetes in Fiji Indians. Med $\mathbf{J}$ Aust 1: 462-463

8. Asmal AC, Dayal B, Jialal I, Leary WP, Omar MAK, Pillay NL, Thandroyen FT (1981) Non-insulin-dependent diabetes mellitus with early onset in Blacks and Indians. S Afr Med J 60: 93-96

9. Rotwein P, Chyn R, Chirgwin J, Cordell B, Goodman HM, Permutt MA (1981) Polymorphism in the $5^{\prime}$-flanking region of the human insulin gene and its possible relation to Type 2 diabetes. Science 213: $1117-1120$

10. Owerbach D, Nerup J (1982) Restriction fragment length polymorphism of the insulin gene in diabetes mellitus. Diabetes 31 : 275-277

11. Rotwein PS, Chirgwin J, Province M, Knowler WC, Pettitt DJ, Cordell B, Goodman HM, Permutt MA (1983) Polymorphism in the $5^{\prime}$ flanking region of the human insulin gene: a genetic marker for non-insulin-dependent diabetes. New Eng J Med 308: 65-71

12. Bell GI, Karam JH, Rutter WJ (1981) Polymorphic DNA region adjacent to the $5^{\prime}$ end of the human insulin gene. Proc Natl Acad Sci USA 78: 5759-5763

13. Ullrich A, Dull TJ, Gray A, Philips JA, Peters S (1982) Variation in the sequence and modification state of the human insulin gene flanking regions. Nucleic Acids Res 10:2225-2240

14. Zimmet P, Kirk R, Serjeantson S, Whitehouse S, Taylor T (1982) Diabetes in Pacific populations-genetic and environmental interactions. In: Melish JS, Hanna J, Baba S (eds) Genetic Environmental Interaction in Diabetes Mellitus, Excerpta Medica, Amsterdam, pp 9-17

15. Serjeantson SW, Kirk RL, Ranford P, Beauchamp MA (1983) HLA antigens and non-HLA chromosome 6 markers in Micronesians from Nauru. Tissue Antigens (in press)

16. Stephen E (1936) Notes on Nauru. Oceania 7: 34-63

17. Viviani N (1970) Nauru: phosphate and political progress. Australian National University Press, Canberra

18. Simpson TB (1844) Pacific navigation and British seamen. The Nautical Magazine and Naval Chronicle, London 13: p 102

19. Zimmet P, Taft P, Guinea A, Guthrie A, Thoma K (1977) The high prevalence of diabetes mellitus on a Central Pacific Island. Diabetologia 13: 111-115

20. W. H.O. Expert Committee on Diabetes Mellitus (1980) Second Report W.H.O. Technical Report Series, No. 646
21. Research Resources Branch, National Institute of Allergy and Infectious Diseases (1976) NIH microcytotoxicity technique. In: Ray JF, Hare D, Pedersen P, Mullally DI (eds) Manual of tissue typing techniques, National Institutes of Health, Bethesda, pp 22-24

22. Owerbach D, BelI GI, Rutter WJ, Shows TB (1980) The insulin gene is located on chromosome 11 in humans. Nature 286:82-84

23. Serjeantson SW, Ryan DP, Thompson AR (1982) The colonisation of the Pacific: the story according to HLA antigens. Am J Hum Genet 34: 904-919

24. Owerbach D, Johansen K, Billesbølle P, Poulsen S, Schroll M, Nerup J (1982) Possible association between DNA sequences flanking the insulin gene and atherosclerosis. Lancet 2: 1291-1293

25. Ranford PR, Kirk RL, Zimmet P (1982) Distributions of complement factors Bf, $\mathrm{C} 2$ and $\mathrm{C} 6$ in the Western Pacific. Acta Anthropogenetica $6: 23-32$

26. Board PG (1980) Genetic polymorphism of human erythrocyte glyoxalase II. Am J Hum Genet 32:690-694

27. Bray GW (1928) Vitamin-B deficiency in infants: its possibility, prevalence and prophylaxis. Trans Roy Soc Trop Med Hyg 22: 9-36

28. Serjeantson SW, Ryan DP, Zimmet P, Taylor R, Cross R, Charpin M, Le Gonidec G (1982) HLA antigens in four Pacific populations with non-insulin-dependent diabetes mellitus. Ann Hum Biol 9: 69-84

29. Owerbach D, Billesbølle P, Poulsen S, Nerup J (1982) DNA insertion sequences near the insulin gene affect glucose regulation. Lancet 1: $880-883$

Received: 28 June 1982

and in revised form: 25 April 1983

Dr. S. W. Serjeantson

Department of Human Biology

John Curtin School of Medical Research

Australian National University

P.O.Box 334

Canberra, ACT

Australia 